\title{
A NEW METERING SYSTEM FOR POTATO TUBERS PLANTER
}

\author{
ATEF E. EL-YAMANI
}

Agric. Eng. Res. Inst. (AEnRI), Giza, Egypt

(Manuscript received 13 March 2011)

\begin{abstract}
A new metering system having vertical rotary disc used for feeding potato tubers planter, manufactured and tested to determine the performance and reducing the operation cost. The modified planter was tested to suit planting potatoes with four traveling forward speeds of 3.1, 3.8, 4.7 and $5.6 \mathrm{Km} / \mathrm{h}$, four planting spaces of $18,24,29$ and 37.5 $\mathrm{cm}$ and three levels of planting depth was 5,7 and $10 \mathrm{~cm}$. The results indicated that, maximum of machine field capacity was $1.2 \mathrm{Fed} / \mathrm{h}$ and field efficiency was $78.5 \%$. Also, maximum of emergence ratio was $98.9 \%$, seed tuber spacing uniformity was $88.5 \%$ and specific fuel consumption was $0.812 \mathrm{l} / \mathrm{kW}$.h. On the other hand, minimum of missing tubers ratio was $0.9 \%$, duality tubers hill ratio was $0.2 \%$. Also, optimum operation cost was $34.5 \mathrm{LE} / \mathrm{h}$ and criterion function was $233.15 \mathrm{LE} / \mathrm{h}$ recorded with forward speed of $4.7 \mathrm{Km} / \mathrm{h}$, planting depth of $5 \mathrm{~cm}$ and planting spaces of 24 $\mathrm{cm}$.
\end{abstract}

\section{INTRODUCTION}

Potatoes are clivated in most of Egypt's governorates. Where, the potatoes are the second most important Egyptian vegetable in terms of value of production as a cash crop. Seed potatoes represent a high portion of production costs for potato farmers. Reducing the cost and improving the quality of planting material for potato production can have an important effect on the productivity and profitability of potato production. The performance of several potato planters has been investigated by many researchers and studies such as, Misener (1997) compared between the cup and pick type planters and found that, the coefficient of variation of spacing ranged from 59.2 to 87.1 and from 55.3 to 68.7 , respectively. The incidence of doubles in relation to the total number of seed pieces was high for both types of planters. The average number of doubles per $30.5 \mathrm{~m}$ of row length ranged from 5 (6.2\% of seed pieces) to 65 (33.6\%) for the cup type and from $5(6.8 \%)$ to $52(29.0 \%)$ for the pick type planter over various forward speeds and nominal spacing. The range of skips for the cup planter was $3(3.2 \%)$ to $22(14.7 \%)$ and for the pick type planter, from $3(3.0 \%)$ to $19(12.1 \%)$ per $30.5 \mathrm{~m}$ of row length. Jasa and Dickey (1982) showed that relative surface roughness, amount of residue present, level of prepare land tillage, and tillage system were important factors affecting spacing uniformity. They also 
concluded that no-till planting could provide at least as uniform a seed spacing as other tillage systems and found that seed spacing uniformity was not affected by planter forward speed. Sharma and Srivastava (1984) evaluated the performance of automatic potato planter with runner type furrow opener in sandy loam. Draft force of potato planter increased with increasing operational speeds. Abdel-Mageed (1986) reported that the width of machine has a significant effect on the field efficiency and that effect increased with decreasing machine width. (Griepentrog, 1998, Karayel and Ozmerzi, 2002) stated that, the main objective of seeding is to put seeds at a desired depth and spacing within the row. Uniform seed spacing and depth result in better germination and emergence and increase yield by minimizing competition between plants for available light, water and nutrients. the potato Griepentrog, 1998 notified that, the quality of horizontal and vertical distribution of seeds is influenced by row spacing, sowing depth, soil conditions, seeder design, seed density, and operator skill. Metwalli et. al. (1998) showed that by increasing planting forward speed both longitudinal and transverse scattering increased. Bader (2002) related yield to the forward speed of an automatic cup potato planter, where the highest yield of 7.05 $\mathrm{t} / \mathrm{ha}$ was obtained when the planter was operated at a forward speed of $3.0 \mathrm{~km} / \mathrm{h}$. ElSahrigi et. al. (2003) reported that planting cut tubers using cup cell at a metering belt speed of $0.6 \mathrm{~m} / \mathrm{s}$ and a drop height of $10 \mathrm{~cm}$ produced a high seed space uniformity of $97.99 \%$.On the contrary, a low space uniformity of $58.7 \%$ was obtained when planting whole seed tubers utilizing a spoon shaped cell at a metering speed of $0.8 \mathrm{~m} / \mathrm{s}$ and a drop height of $30 \mathrm{~cm}$. Ghonimy and Rostom (2005) found that potato yield reached up to $20.95 \mathrm{t} / \mathrm{ha}$ with a cup-chain prototype planter when compared to $19.52 \mathrm{t} / \mathrm{ha}$ with a cup-chain prototype planter. They also stated that the automatic cup-feeding system exhibited the best performance compared to the automatic chain and the semi-automatic tray feeding systems. In addition, they concluded that higher coefficient of variation was found with auto-feed cup planter compared to planters with either single or multi-feed belts. Dean and Thomas (2007) a multi-year research project comparing potato planting configurations required a mechanical, plot-scale (two-row) planter capable of planting in both a conventional (hill or ridge) mode and in a furrow or trench mode. Both planter redesigned were used successfully in the field for small plot experiments. The main objective was to design and develop a machine that had a simple mechanism, easy to repair and maintain and, equally important, could be manufactured locally at a cost affordable to domestic farmers. Celik, et. al. (2007) reported that, four different type seeders were evaluated for seed spacing, depth uniformity, and plant emergence at three forward speeds 3.6, 5.4, and $7.2 \mathrm{~km} / \mathrm{h}$. The planter types were: no-till planter, precision vacuum planter, universal 
planter, and semi-automatic potato planter. The best seed spacing uniformity and seed emergence ratio were obtained with the no-till planter, and the best seed depth uniformity was obtained with the precision vacuum planter. Forward speed significantly affected only the mean emergence time $(P<0.05)$. Ismail (2007) mentioned that, potato planting is considered as a very crucial and critical operation because it directly affects the yield and the farming cost, as the price of potato tubers mounts to about $60 \%$ of the total potato production cost. The problem, there is in the market two types of potato tubers Planters. First machine named half-automatic feeding and another automatic feeding. At planting potato both qualitative consumes a high rate of tubers and also both need a specialist worker to control the machine. So, this is the additional cost on the machine where, the first feeds manually and another feed by chains and cups. The idea of this research is to fabricate new metering system for feeding tubers. This metering system is cylindrical with a vertical position and riding on the surrounding cups input only accepts tuber where one allows the new system feeding to fall excess tubers into the machine to re-fed again worked to provide the amount of tubers and reduce the number of unfair and irregular tubers dual feed on equal distances. The objective of this study was to:

1-Designing and fabricating a new cylindrical metering system for potatoes planter.

2-Investigation the effect of forward speed, tuber planting spacing, planting depth to evaluate the current university recommendation to planting potatoes under different operation condition.

3-Investigation the factors affecting operational cost of this machine.

\section{MATERIALS AND METHODS}

This study was conducted at private sector farm in West Nubaria during the potatoes planting season of 2011. Whole seed tubers, average seed weight of 35 to $50 \mathrm{~g}$ for Spunta variety (have oval shape) were planted .Seed preparation was done using moldboard plowing, disc harrowing and leveling. Some physical properties of the experimental field are given in Table1.

Table 1 . Soil physical properties for the 0 to $0.1 \mathrm{~m}$ depth range.

\begin{tabular}{|l|l|}
\hline Physical Property & Value \\
\hline Bulk density (Mg m-3) & 1.65 \\
\hline Porosity (\%) & 46.1 \\
\hline Moisture content (\% d.b.) & 16.7 \\
\hline Penetration resistance (MPa) & 0.931 \\
\hline Textural class & silt clay loam \\
\hline Soil particular size $<8 \mathrm{~mm} \mathrm{( \% )}$ & 61.82 \\
\hline
\end{tabular}




\section{Modifying potato tuber planter}

The main components of using machine after modifying is shown in Fig.1 and Fig. 2. This machine is a single-row have width 1 meter, hitching-type pick potato planter. The main frame is fabricated in three sections and is supported by two wheels. It is designed for use by the tractor driver and type of drive by chain and gear from ground wheel. The seed hopper is equipped with 80 liters seed hopper placed above one picker bowl. A picker wheel assembly (feeding rotary disc) Fig.3, containing 8 cam-activated picker cups, is located in each picker bowl. Steel picks on each picker arm pierce the seed, carry it out of the picker bowl as in Fig.4. and drop it through seed chutes into furrows formed by the planting shoes. Seed spacing can be varied by changing drive sprockets while seed depth is controlled by adjustable linkages and a hydraulic cylinder. Two covering disks form soil hill over seed row.

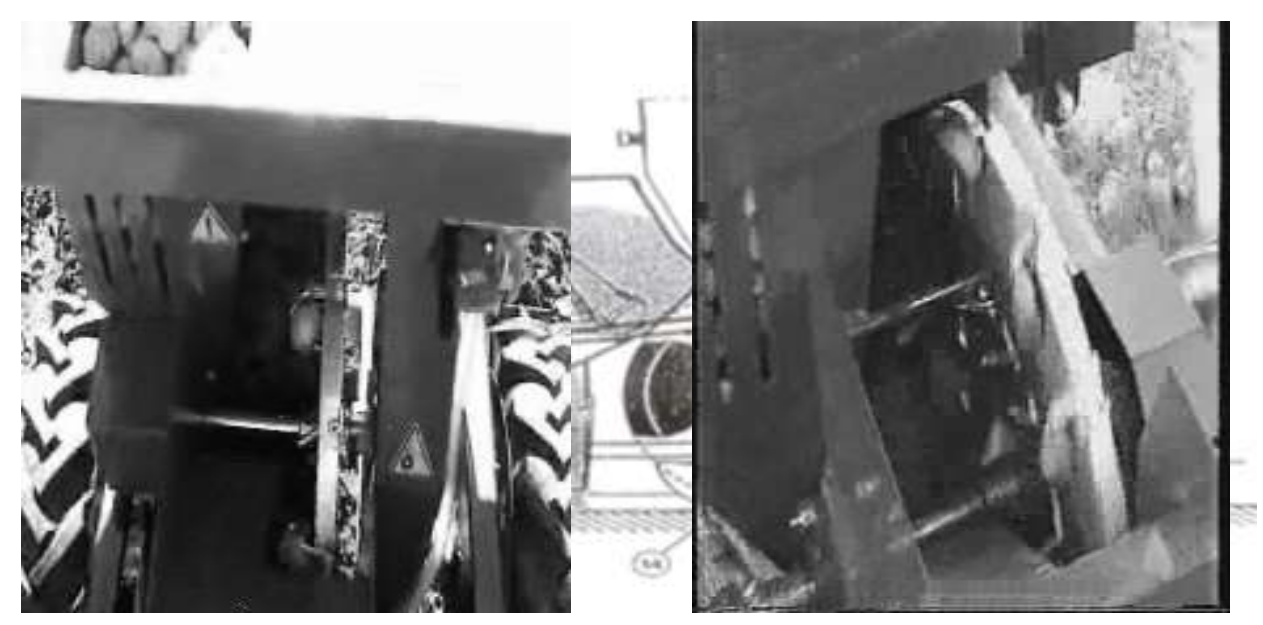

Fig. 1. A new manufactured metering system used in potato tubers planter.

\begin{tabular}{|c|c|c|}
\hline 1- Opening disk & 2-Čultivator tooth, & 3- Adjustable linkage \\
\hline 4-Fertilizer feed hose & $\begin{array}{l}\text { 5-Fertilizer feed } \\
\text { chain }\end{array}$ & 6- Fertilizer gate \\
\hline 7- Fertilizer agitator & 8-Fertilizer hopper & 9- Seed hopper \\
\hline 10- Seed gate & 11- Picker bowl & 12- Closing disk \\
\hline 13- Seed chute & 14-Planting shoe & \\
\hline
\end{tabular}

Fig. 2. Schematic of using potato planter 
1-Pick-up point 2-Drop point 3-Picker arm

4-Picks 5-Stringer arm

Fig. 3. A new manufactured metering system (vertical rotary disc).

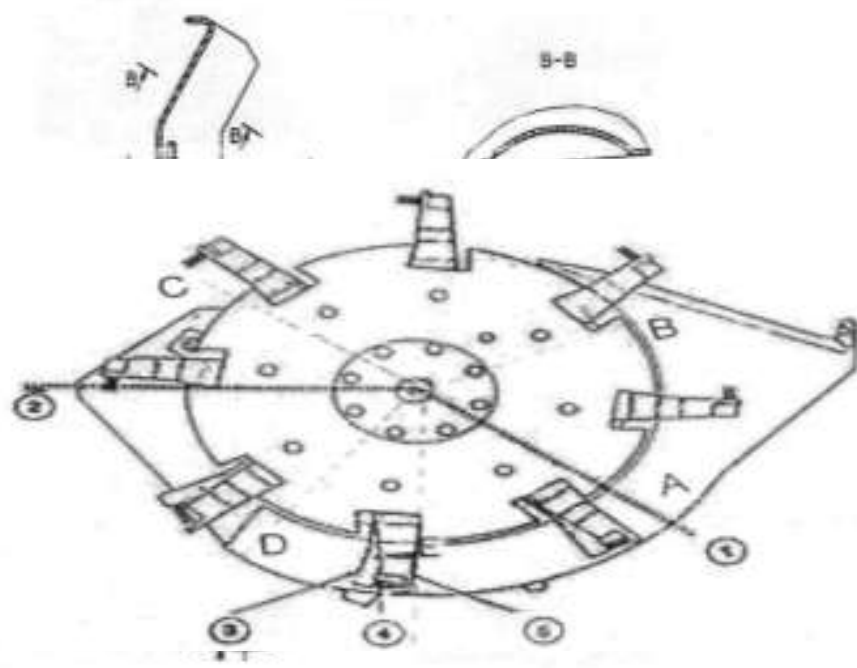

1-Disc support. 2-The cup 3-The metallic cup.

Fig. 4. View of the used cup of the planting metering system.

\section{Suggested Modification}

1- A modifying the vertical cylindrical-type distribution systems equipped with special cups are manufactured and used in this research. A new metering system (vertical rotary disc) was made up of a cylinder link on which there were erected pick up 
cups, spaced at a certain pitch (Fig. 3). The cylinder link was made up of four main branches: $\boldsymbol{A} \boldsymbol{B}$ portion, a branch with an ascending vertical movement having the role of overtaking the potato tubers from the feeding hopper, $\boldsymbol{B C}$ portion representing a circular arc with of transporting the planting material, $\boldsymbol{C D}$ portion with the wrapping angle bigger than $90^{\circ}$ on which the release of the potato tubers takes place, $\boldsymbol{D E}$ portion which allow to the potato tubers takes out, $\boldsymbol{E A}$ portion represents the oblique branch of the planting apparatus on which the cups are in contact with the potato tubers on their rear part. Where:

-Potato tubers velocity occurring in the metering system tubers velocity occurs in the metering system while tubers were thrown by the cups (Klenin et al., 1986). The speed of revolution of the buckets and the theoretical seed tuber spacing was calculated at the forward speed of the machine ranged from $3.1-5.6 \mathrm{Km} / \mathrm{h}$, as presented by:

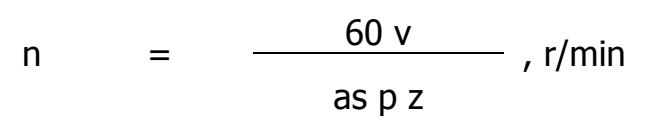

When slip was

$$
v=v S\left[1+\frac{S}{100}\right]
$$

Where:

$$
\begin{aligned}
\mathrm{n} & =\text { speed of the disk rotation, } \mathrm{r} / \mathrm{pm}, \\
\mathrm{v} & =\text { speed of the machine, } \mathrm{m} / \mathrm{s}, \\
\mathrm{vs} & =\text { peripheral speed of the wheel, } \\
\mathrm{S} & =\text { wheel slippage (10-12 percent), } \\
\text { as } & =\text { the spacing between tubers in a row, } \mathrm{m}, \\
\mathrm{z} & =\text { number of cups on arotaty disk, } \\
\mathrm{p} & =\text { number of tubers for each cup. }
\end{aligned}
$$

-Tubers velocity at the beginning of the chute tubers velocity thrown from the cups is presented as:

$$
\text { vo }=\frac{2 \pi r n}{60}
$$


Where:

$$
\begin{aligned}
\mathrm{vo}= & \text { tubers velocity in cups, } \mathrm{m} / \mathrm{s}, \\
\mathrm{r}= & \text { turning radius (distance from the center of the tubers in a } \\
& \text { cup and the center of rotation), } \mathrm{m} .
\end{aligned}
$$

-Tubers velocity at the end of the chute The theory of material flowing on an inclined plate (Mohsenin, 1986) used, was:

$\mathrm{v}^{2}=2 \mathrm{gh}(1-\mu \cot \beta)+\mathrm{vo}^{2}$

Where:

$\mathrm{v} 2=$ tubers velocity at the end of the chute, $\mathrm{m} / \mathrm{s}$,

$\mathrm{h}=$ height of the chute in the vertical direction, $(0.15 \mathrm{~m}), \mathrm{m}$,

$\mu=$ coefficient of friction between tubers and the chute, $(0.22)$,

$\beta=$ chute angle, $\left(30^{\circ}\right)$, degrees

2- Seed spacing was adjusted by varying the picker wheel and axle drive sprockets. Seed spacing of $85 \mathrm{~mm}$ to $475 \mathrm{~mm}$ were possible.

3- Adjustment of the planting depth was through an adjustable linkage.

\section{Investigated variables:}

1- Forward speed: Four forward speeds of $3.1,3.8,4.7$ and $5.6 \mathrm{~km} / \mathrm{h}$, were used in this study.

2-Planting depth: Three planting depth were used as follows 5 , 7and $10 \mathrm{~cm}$.

3- Seed tuber planting spacing: Four ratios of forward speeds to feeding mechanism speed were $1.14,1.28,1.43$, and 1.71 , this would give a theoretical seed tuber spacing of $18,24,29$ and $37.5 \mathrm{~cm}$, respectively.

4- Feeding gate heights was $20 \mathrm{~cm}$.

Different combination of treatments were replicated three times

\section{Measuring procedures}

1- Field efficiency : The field efficiency was calculated from the following equation:

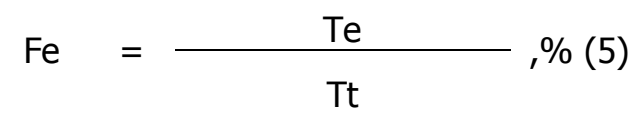

Where:

$$
\begin{aligned}
\mathrm{Fe} & =\text { field efficiency, } \%, \\
\mathrm{Te} & =\text { effective operating time, min, and }
\end{aligned}
$$


$\mathrm{Tt}=$ total operating time, min.

2- Effective field capacity : The effective field capacity was calculated as follows:

$$
\text { E.F.C }=\frac{\text { s w e }}{4.2} \text {, fed/h (6) }
$$

Where:

$$
\begin{aligned}
& \text { E.F.C }=\text { the effective field capacity, fed/h, } \\
& s=\text { speed of travel, } \mathrm{Km} / \mathrm{h}, \\
& w=\text { rated width of implement, } \mathrm{m}, \text { and } \\
& \mathrm{e}=\text { field efficiency, } \% .
\end{aligned}
$$

3-Emergence ratio: emerged seeds were counted several times during the emergence period in the rows with $10 \mathrm{~m}^{2}$ for each treatment and It were calculated according to next formula (Bilbro and Wanjura, 1982).

PE

$$
=\frac{\text { TES }}{\text { NSP }} \times 100, \%
$$

Where:

$$
\begin{aligned}
& \text { TES }=\text { number of plants } / 10 \mathrm{~m}^{2}, \text { and }, \\
& \text { NSP }=\text { number of delivered tuber cells } / 10 \mathrm{~m}^{2} .
\end{aligned}
$$

4- Missing tubers ratio : it was determined by using the following formula:

$$
\mathrm{Vt}=\frac{\mathrm{Mn}}{\mathrm{M}} \times 100, \%(8)
$$

Where

$\mathrm{Vt}=$ missing tubers ratio, \%,

$M=$ buckets number at limited time from metering system operation,

$\mathrm{Mn}=$ row spacing numbers $(\mathrm{Sc})$ at the same limited time.

$$
\text { Also, Sc } \geq 2 \text { St, } 9
$$

Where:

St $=$ theoretical spacing which machine adjusted.

5- Duality hill ratio : it was calculated by the following formula:

$$
\mathrm{VL}=\frac{\mathrm{M} \mathrm{t}}{\mathrm{M}} \times 100, \%(10)
$$

Where:

$\mathrm{VL}=$ duality hill ratio, $\%$ 
$M=$ buckets number at limited time from metering system operation,

$\mathrm{Mt}=$ row spacing numbers $(\mathrm{Sc})$ at the same limited time.

Also, Sc $\leq 1 / 2$ St, (11)

6- Seed tuber spacing uniformity: It was evaluated by using standard deviation equation

7- Specific fuel consumption: Required power can be calculated by using the following formula (Hunt, 1983):

$E P=[f . c(1 / 3600) \rho E \times$ L.C.V. $\times 427 \times \eta$ thb $\times \eta m \times 1 / 75 \times 1 / 1.36], k W . . .(12)$

Where:

$\mathrm{EP}=$ required power, $\mathrm{kW}$,

f.c $=$ the fuel consumption, $\mathrm{l} / \mathrm{h}$,

$\rho \mathrm{E} \quad=$ density of the fuel, $\mathrm{kg} / \mathrm{l}$ (for solar fuel $=0.85$ ),

L.C.V = lower calorific value of fuel (for solar fuel is $11000 \mathrm{kcal} / \mathrm{kg}$ ),

$427=$ thermal- mechanical equivalent, $(\mathrm{w} / \mathrm{kcal}$.$) ,$

nthb $=$ thermal efficiency of the engine( $35 \%$ for Diesel), and

$\eta \mathrm{m}=$ mechanical efficiency of the engine( $80 \%$ for diesel).

Specific fuel

consumption

$$
=\frac{\text { Fuel consumption, } \mathrm{l} / \mathrm{h}}{\text { Power consumed, } \mathrm{kW}}, \mathrm{l} / \mathrm{kW} \cdot \mathrm{h}
$$

8-Total cost analysis: Including fixed and operating costs. Declining balance method was used to determine the depreciation (Hunt, 1983).

Operating cost

$$
=\frac{\text { Machine cost , LE/h }}{\text { Effective field capacity , fed/h }} \text {, }
$$

LE/fed...(14)

Criterion Function Cost, LE/fed = Operating cost, LE/fed + Losses cost, LE/fed

-Losses cost are considered as total decreasing in productivity caused from missing value of mechanical planting hill .

\section{RESULTS AND DISCUSSION}

\section{1- Effective field capacity and field efficiency}

Results in Figs. $\mathbf{5}$ and $\mathbf{6}$ showed the effect of forward speed, planting depth and seed row planting space on effective field capacity and field efficiency. Its illustrated too that, forward speed was the most important factor affected on field capacity and field efficiency. Where, effective field capacity was increasing with increase of forward speed and seed row planting space while, it was decreased with increasing planting 
depth. Whereas, at planting depth of $5 \mathrm{~cm}$ and seed row planting space of $18 \mathrm{~cm}$ by increasing forward speed from 3.1 to $5.6 \mathrm{Km} / \mathrm{h}$ effective field capacity increase from 0.6 to $0.95 \mathrm{fed} / \mathrm{h}(+58.3 \%)$.

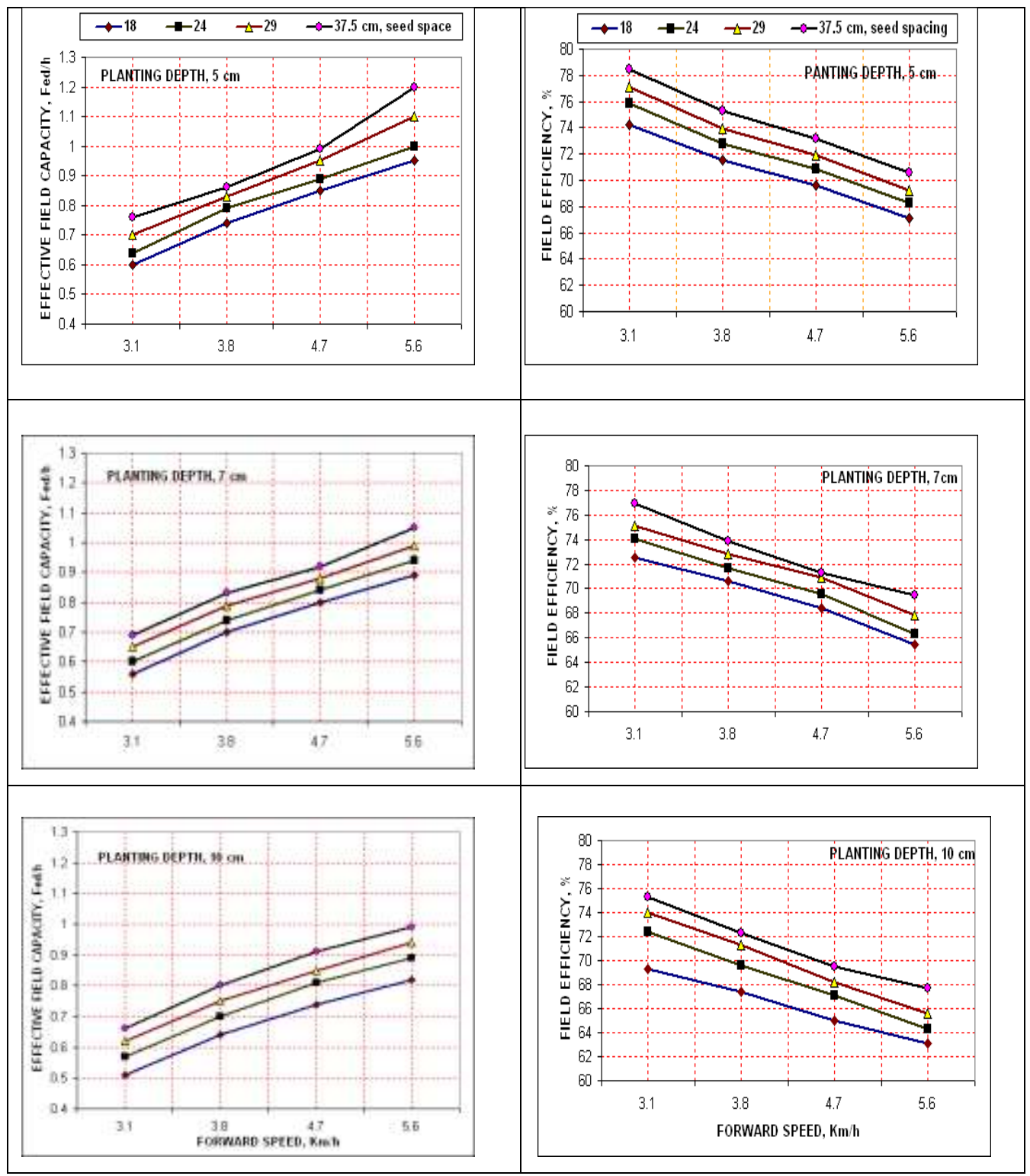


Fig. 5. Effect of forward speed and seed row planting space on effective field capacity for different levels of planting depth.
Fig. 6. Effect of forward speed and seed row planting space on field efficiency for different levels of planting depth.

Also, at planting depth of $5 \mathrm{~cm}$ and forward speed of $3.1 \mathrm{Km} / \mathrm{h}$, by increasing seed row planting space from 18 to $37.5 \mathrm{~cm}$ effective field capacity increase from 0.6 to $0.76 \mathrm{fed} / \mathrm{h}(+26.6 \%)$. While, at forward speed of $3.1 \mathrm{Km} / \mathrm{h}$, seed row planting space of $18 \mathrm{~cm}$ by increasing planting depth from 5 to $10 \mathrm{~cm}$, effective field capacity decrease from 0.6 to $0.51 \mathrm{fed} / \mathrm{h}(-15 \%)$. On other hand, field efficiency was decreasing with increase of forward speed and planting depth while, it was increased with increasing of seed row planting space. Whereas, field efficiency was decreased from 74.2 to $67.1 \%(-9.56 \%)$ at increasing forward speed from 3.1 to $5.6 \mathrm{Km} / \mathrm{h}$ with seed row planting space of $18 \mathrm{~cm}$ and planting depth of $5 \mathrm{~cm}$. also, field efficiency was decreased from 74.2 to $69.3 \%(-6.6 \%)$ at increasing planting depth from $5 \mathrm{~cm}$ to $10 \mathrm{~cm}$ with forward speed of $3.1 \mathrm{Km} / \mathrm{h}$ and seed row planting space of $18 \mathrm{~cm}$. While, field efficiency was increased from 74.2 to $78.5 \%(+5.8 \%)$ at increasing seed row planting space from 18 to $37.5 \mathrm{~cm}$ with forward speed of $3.1 \mathrm{Km} / \mathrm{h}$ and planting depth of $5 \mathrm{~cm}$.

\section{2- Emergence ratio and missing tubers ratio}

Result in Fig. 7 and 8 shows the relationship between forward speed and both of emergence ratio and missing tubers ratio at different levels of planting depth and seed row planting space indicated that, increasing all of forward speed, seed row planting space and planting depth led to decrease emergence ratio. While, increasing all of forward speed, planting depth and seed row planting space led to increase missing ratio. Where, the emergence ratio decreased from 98.9 to $94.8 \%(-4.14 \%)$ by increasing forward speed from 3.1 to $5.6 \mathrm{Km} / \mathrm{h}$ at planting depth of $5 \mathrm{~cm}$ and seed row planting space of $18 \mathrm{~cm}$. Also, the emergence ratio decreased from 98.9 to 98.2 $\%(-0.7 \%)$ by increasing planting depth from 5 to $10 \mathrm{~cm}$ with forward speed of 3.1 $\mathrm{km} / \mathrm{h}$ and seed row planting space of $18 \mathrm{~cm}$. While, the emergence ratio decreased from 98.9 to $97.5 \%(-1.4 \%)$ by increasing seed row planting space from 18 to 37.5 $\mathrm{cm}$ with forward speed of $3.1 \mathrm{Km} / \mathrm{h}$ and planting depth of $5 \mathrm{~cm}$. On other hand, missing tubers ratio was increased from 0.9 to $3.9 \%$ (+333\%) by increasing forward speed from 3.1 to $5.6 \mathrm{Km} / \mathrm{h}$ with planting depth of $5 \mathrm{~cm}$ and seed row planting space of $18 \mathrm{~cm}$. Also, missing tubers ratio was increased from 0.9 to $1.1 \%(+22.2 \%)$ by increasing planting depth from 5 to $10 \mathrm{~cm}$ with forward speed of $3.1 \mathrm{Km} / \mathrm{h}$ and seed row planting space of $18 \mathrm{~cm}$. While, it was increased from 0.9 to $1.7 \%(+88.8 \%)$ by 
increasing seed row planting space from 18 to $37.5 \mathrm{~cm}$ with forward speed of 3.1 $\mathrm{km} / \mathrm{h}$ and planting depth of $5 \mathrm{~cm}$. Results shown too that, maximum value of emergence ratio was $98.9 \%$ and minimum value of missing tubers ratio was $0.9 \%$ recorded at forward speed of $3.1 \mathrm{Km} / \mathrm{h}$, planting depth of $5 \mathrm{~cm}$ and seed row planting space of $18 \mathrm{~cm}$, respectively. Finally, from Fig. 7 and 8 become clear that, forward speed is the most influential factor on the percentage of emergence and missing tubers followed by planting depth while, seed row planting space slightly effect. As, the tubers mechanical state depends on the friction coefficient between the tuber, the cup and the wall were done and increased with increasing of forward speed and planter parts speed making damage in potato sprout, so that emergence ratio was decreased. In addition to miss same cup from potato because of velocity.

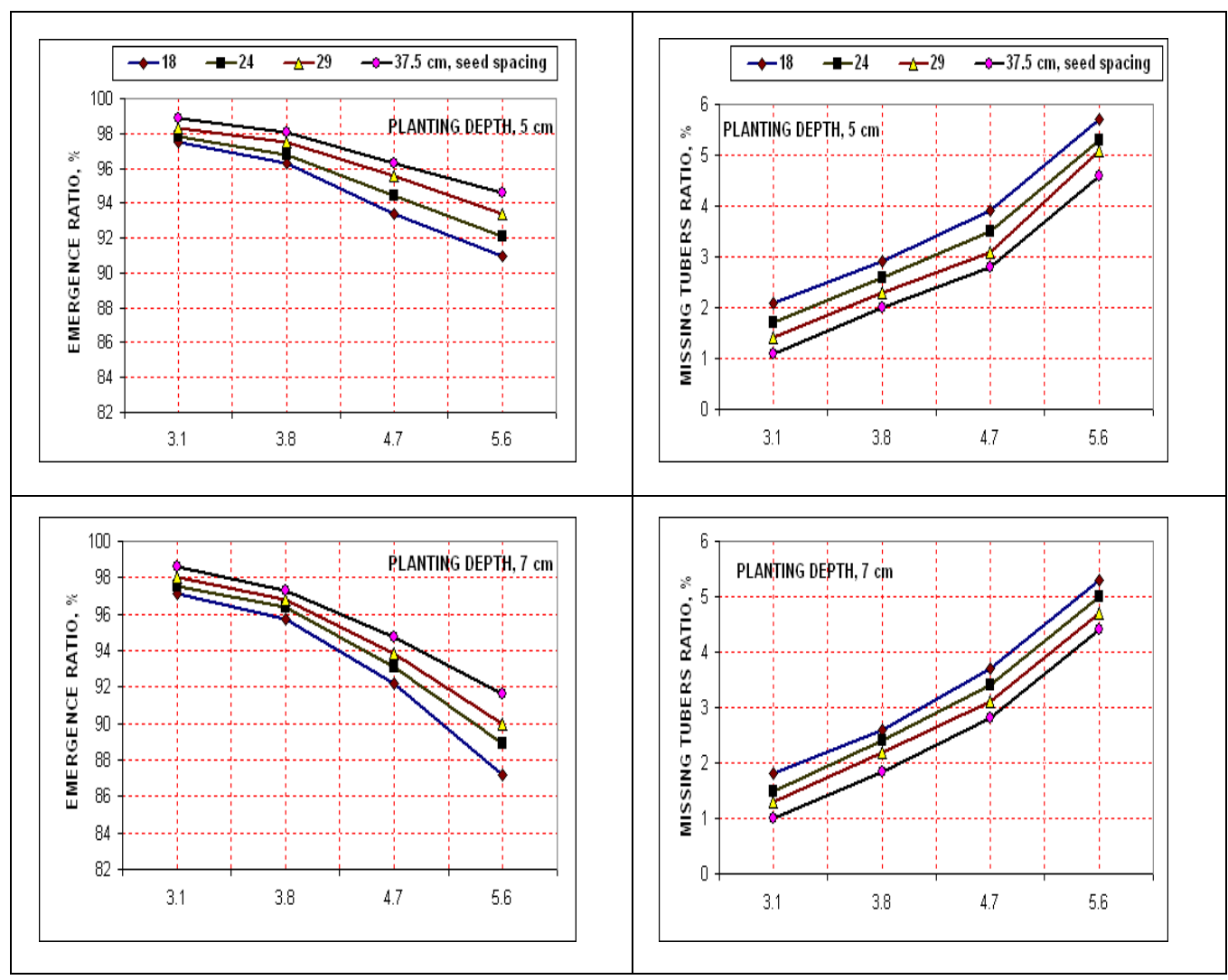




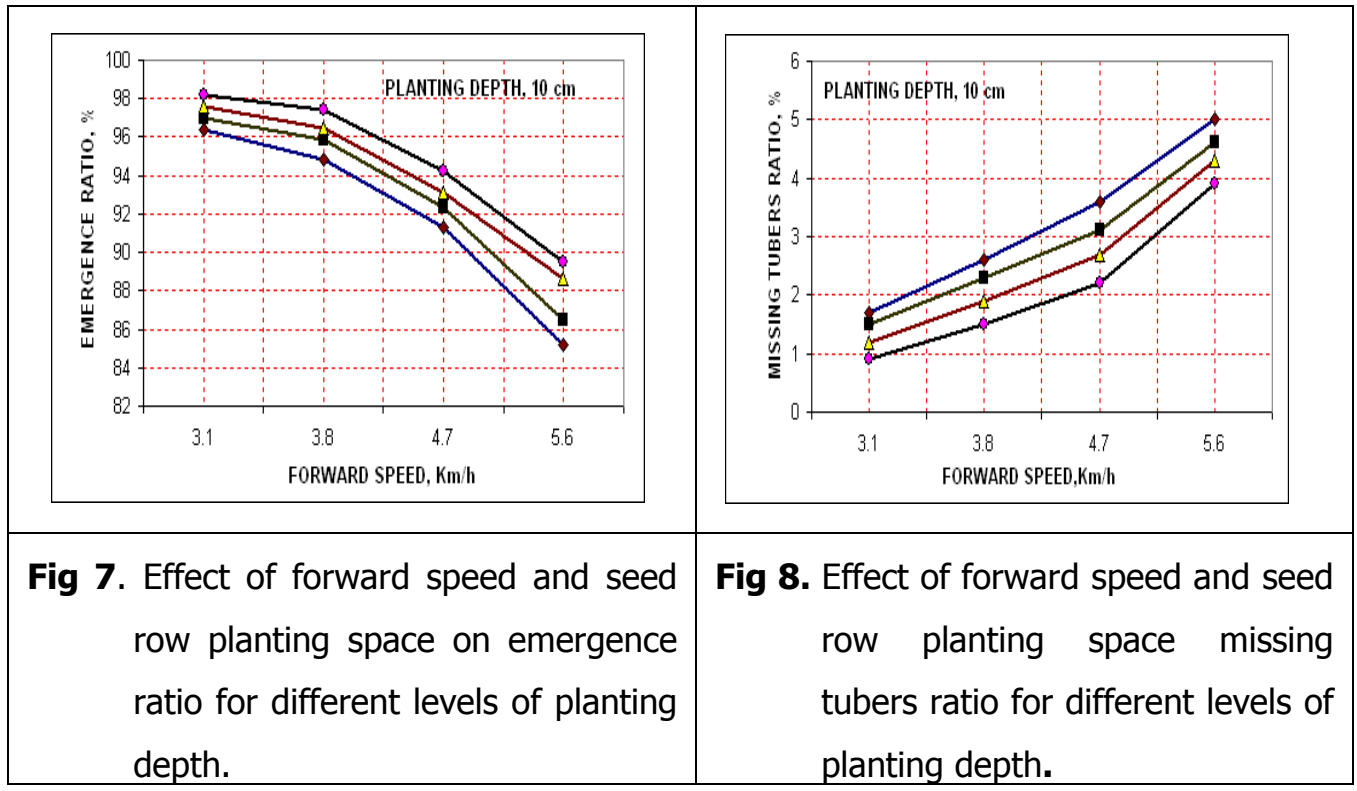

\section{3- Duality hill ratio}

Results in Fig. 9 indicated that at optimum operation conditions, forward speed was the most important factor affected on duality hill ratio. Whereas, duality hill ratio was increased with increasing of forward speed and increasing of seed row planting space. While, it no effect from planting depth. So, duality hill ratio was increasing from 1.3 to $2.6 \%(+100 \%)$ by increasing forward speed from 3.1 to 5.6 $\mathrm{Km} / \mathrm{h}$ at seed row planting space of $37.5 \mathrm{~cm}$. While, it was decreasing from 1.3 to 0.8 $\%(-38.5 \%)$ by decreasing seed row planting space from 37.5 to $18 \mathrm{~cm}$ at forward speed of $3.1 \mathrm{Km} / \mathrm{h}$.

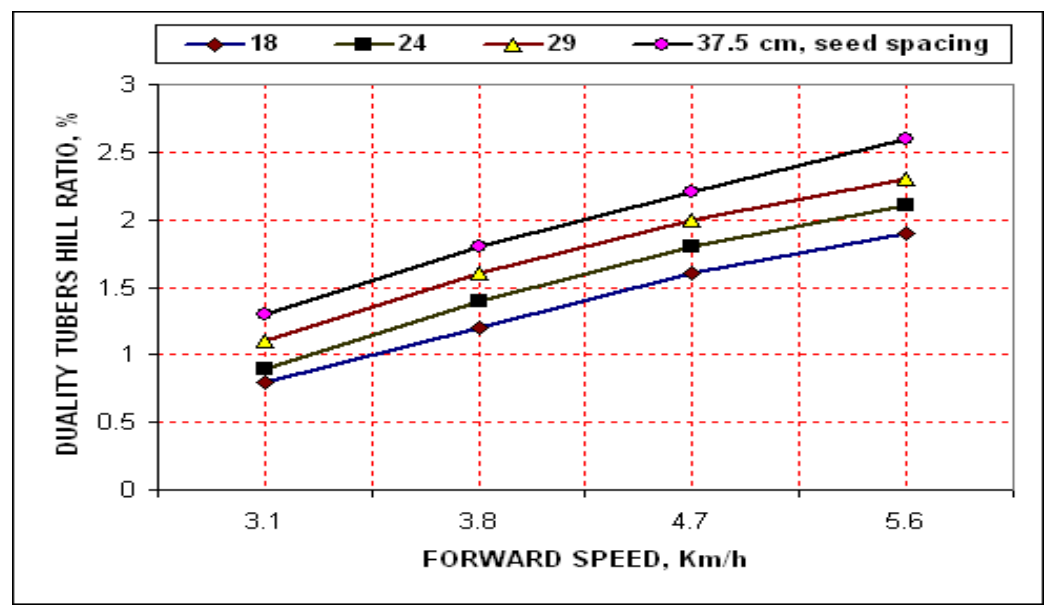

Fig. 9. Effect of forward speed and seed row planting space on duality hill ratio.

\section{4-Uniformity tubers ratio}


Results in Fig. 10 shown the effect of forward speed and seed row planting space at optimum operation condition. Whereas, uniformity tubers ratio was decreasing from 88.5 to $80.3 \%$ by increasing forward speed from 3.1 to $5.6 \mathrm{Km} / \mathrm{h}$ at seed row planting space of $18 \mathrm{~cm}$. also, uniformity tubers ratio was decreasing from 88.5 to 84 $\%$ by increasing seed row planting space from 18 to $37.5 \mathrm{~cm}$ at forward speed of 3.1 $\mathrm{Km} / \mathrm{h}$.

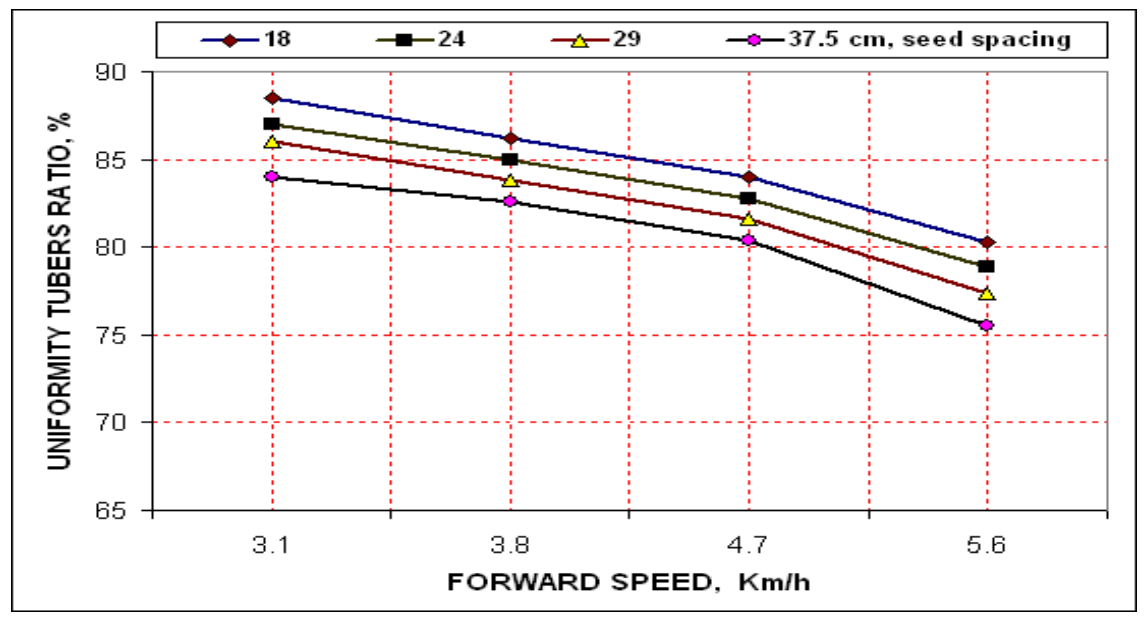

Fig. 10. Effect of forward speed and seed row planting space on uniformity tubers ratio.

\section{5- Specific fuel consumption}

Specific fuel consumption as connected with planting forward speed, seed row planting space and planting depth are shown in Fig. 11 results noticed that, specific fuel consumption was decreased with increase of forward speed and with increase planting depth while it was increased with increasing seed row planting space. Whereas, increasing forward speed from 3.1 to $5.6 \mathrm{Km} / \mathrm{h}$ at planting depth of $5 \mathrm{~cm}$ and seed row planting space of $18 \mathrm{~cm}$ tends to decreasing specific fuel consumption from 0.743 to $0.604 \mathrm{l} / \mathrm{kW} . \mathrm{h}(-18.7 \%)$. Also, by increasing planting depth from 5 to $10 \mathrm{~cm}$ at forward speed of $3.1 \mathrm{~km} / \mathrm{h}$ and seed row planting space of $18 \mathrm{~cm}$ tends to decreasing specific fuel consumption from 0.743 to $0.602(-19 \%)$. While, by increasing seed row planting space from 18 to $37.5 \mathrm{~cm}$ at forward speed of $3.1 \mathrm{Km} / \mathrm{h}$ and planting depth of $5 \mathrm{~cm}$ tends to increasing specific fuel consumption from 0.743 to $0.812 \mathrm{l} / \mathrm{kW} \cdot \mathrm{h}(+9.29 \%)$.

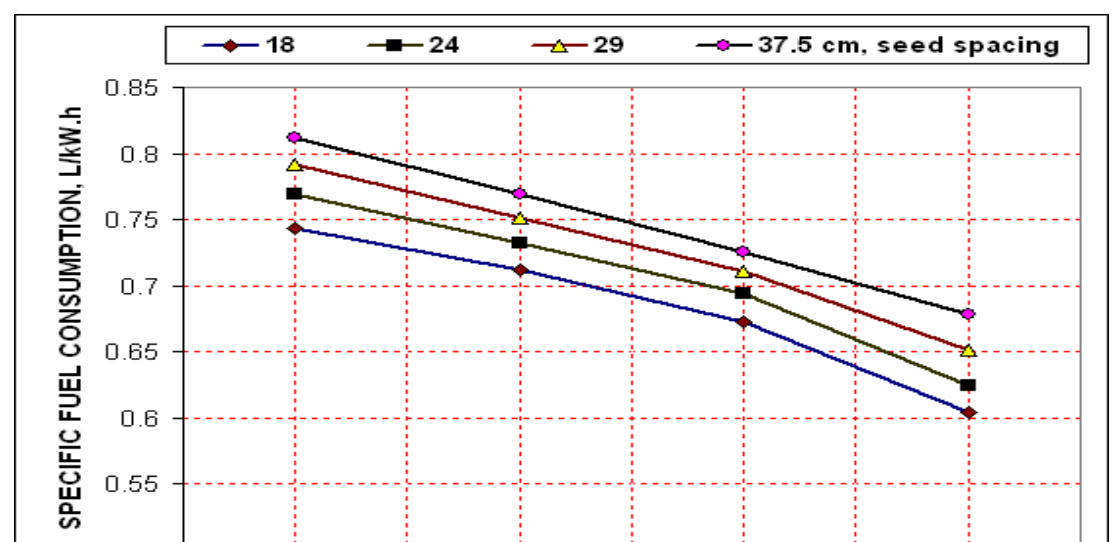


Fig. 11. Effect of forward speed and seed row planting space on specific fuel consumption.

\section{6- Operation cost and Criterion function cost :}

Results as shown in Table $\mathbf{2}$ indicated that, the mean calculated items of cost analysis for using tractor and potato tuber planter equal 34. $5 \mathrm{LE} / \mathrm{h}$ while marketplace prices for similar machines equal $80 \mathrm{LE} / \mathrm{h}$. On other hand, as shown in Fig. 12 criterion function cost tends to increase with increasing all of forward speed, planting depth and seed row planting space. It can noticed that, increasing forward speed from 3.1 to $5.6 \mathrm{Km} / \mathrm{h}$ at planting depth of $5 \mathrm{~cm}$ and seed row planting space of $18 \mathrm{~cm}$, criterion

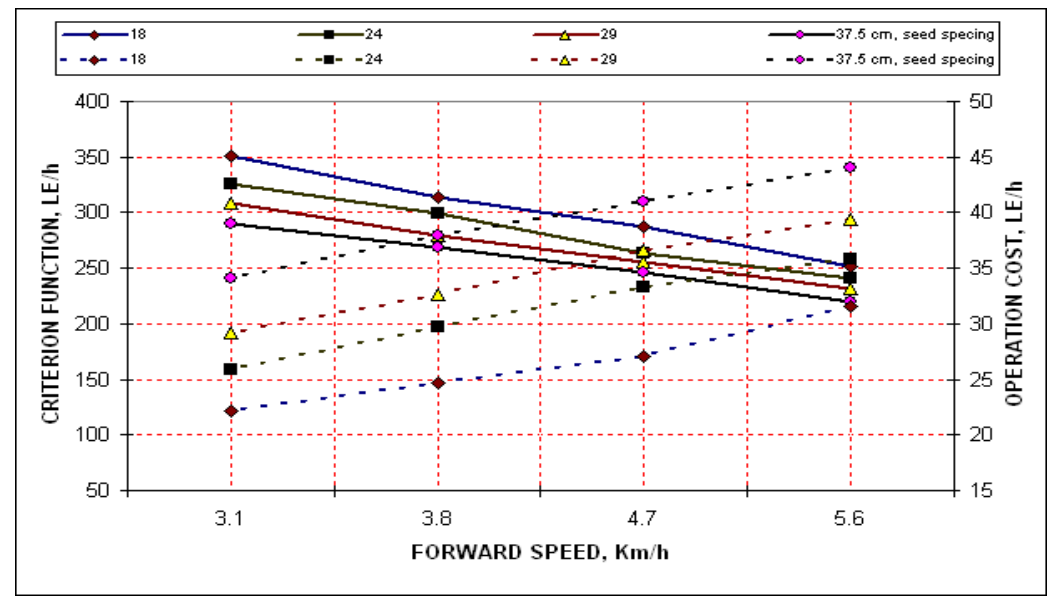

Fig. 12. Effect of forward speed and seed row planting space on operation cost and criterion function cost at planting depth $5 \mathrm{~cm}$.

function cost increased from 121.43 to $215.83 \mathrm{LE} /$ fed $(+77.74 \%)$. Also, by increasing seed row planting space from 18 to $37.5 \mathrm{~cm}$ at forward speed of $3.1 \mathrm{Km} / \mathrm{h}$, criterion function cost increased from 121.43 to 241.09 LE/fed (+98.54\%).from figure 12 , it can be noticed that, the useful forward speed for optimum operation cost was 4.7 $\mathrm{Km} / \mathrm{h}$.

Table 2. The mean items of cost analysis 


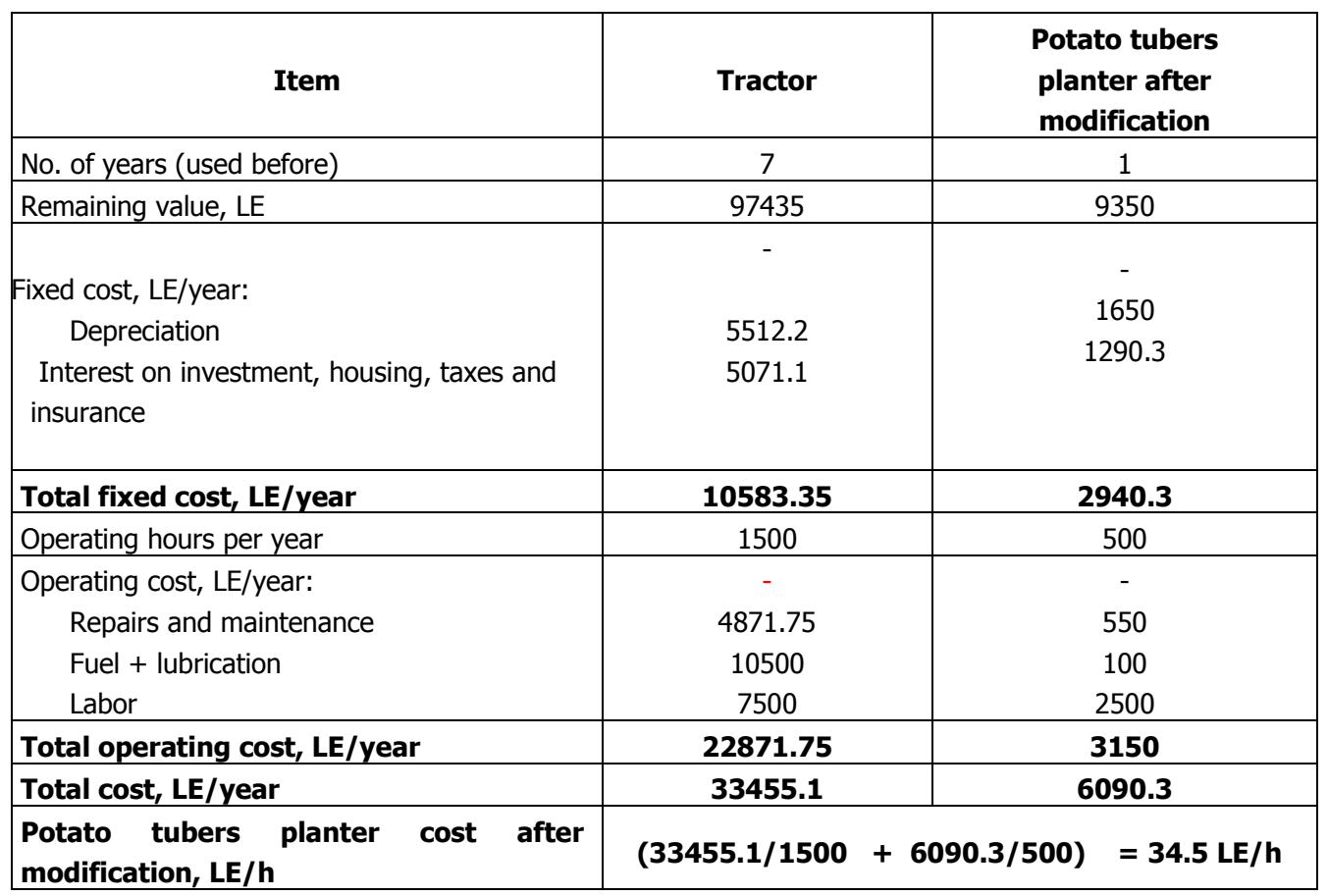

\section{CONCLUSION}

\section{The characteristics conclusion could be summarized as follows}

1- The optimum operation condition for modify potatoes planter with a new metering system having rotary disc were as follows: forward speed of $4.7 \mathrm{Km} / \mathrm{h}$, planting depth of $5 \mathrm{~cm}$ and seed row planting space of $18 \mathrm{~cm}$.

2- The maximum of emergence ratio was $98.9 \%$, uniformity tubers ratio was $88.5 \%$ and minimum of missing tubers ratio was $0.9 \%$ recorded at forward speed of 3.1 $\mathrm{Km} / \mathrm{h}$, planting depth of $5 \mathrm{~cm}$ and seed row planting space of $18 \mathrm{~cm}$.

3- The maximum of field efficiency was $78.5 \%$ and effective field capacity was 1.2 fed/h recorded at planting depth of $5 \mathrm{~cm}$, seed row planting space of $37.5 \mathrm{~cm}$ and forward speed of 3.1 and $5.6 \mathrm{Km} / \mathrm{h}$ respectively.

4- The maximum specific fuel consumption $0.812 \mathrm{l} / \mathrm{kW}$.h was found at forward speed of $3.1 \mathrm{Km} / \mathrm{h}$, planting depth of $5 \mathrm{~cm}$ and seed row planting space of $37.5 \mathrm{~cm}$.

5- At optimum operation condition the operation cost value was $34.5 \mathrm{LE} / \mathrm{h}$ while criterion function cost was $233.15 \mathrm{LE} / \mathrm{h}$.

\section{REFERENCES}

1- Abdel - Mageed, H. N. 1986. Economical machinery systems for small opener. Misr. J. Ag. Eng., 16 (2): 176-192. 
2- Bader,S.E.,2002. Requirements of potato mechanical planting when intercropping with vine grapes. Misr J. Ag. Eng., 19(3):775-788.

3- Bilbro, J.D. and D.F.Wanjura, 1982. Soil crusts and cotton emergence relationships. . Transactions of the ASAE 25(6): 1484-1487.

4- Celik,a. , I. Ozturk and T. R. Way. 2007. Effects of Various Planters on Emergence and Seed Distribution Uniformity of Sunflower. Aeae Soc. of Agr. Eng., Vol. 23(1): 57-61.

5- Dean D. Steele and Thomas A. Bon. 2007. Potato Planter Development via Capstone Design and Engineering Tools. the American Society of Agricultural and Biological Engineers (ASABE), Minneapolis Convention Center Minneapolis, Minnesota.

6- El-Sahrigi, A.F., A.E.Abou-Elmagd, E.A. Amin and M.M. Abdel-Galil. 2003. Development of a potato planter for planting cut seeds in a double-row ridge. Misr J. Ag. Eng., 20(4):487-507.

7- Ghonimy, M.I. and M.N. Rostom. 2005. Evaluation of auto-feed potato planters. Misr J. Ag. Eng., 22(1):1-14.

8- Griepentrog, H. W. 1998. Seed distribution over the area. Eur. Ag. Eng. 98-A-059, slo.

9- Hunt, D. 1983. Farm power and machinery management. 8th Ed. Iowa state Univ., Press Ames,Iowa, USA: 364-368.

10- Ismail, Z. E. 2007. The triangle belt provided with spoons to plant potato tuber with sprouts. J. Ag. Sci. Mansoura Univ., Egypt., 32(11):9093-9108.

11- Jasa, P. J., and E. C. Jickey. 1982. Tillage factors affecting corn seed spacing. Trans. of the ASAE 25(6): 1516-1519.

12- Karayel, D., and A. Ozmerzi. 2002. Effect of tillage methods on sowing uniformity of maize. Canadian Biosystems Engineering 44: 2.23-2.26.

13- Klennin N. I., I. F. Popov and V. A. Sakun. 1986.Agricultural Machines Printing Work, New Delhi. 129-158.

14- Metwalli, M. M., M. A. K. El-Said and S. I. Yousef. 1998. Performance evaluation of some planting machinery sugar beet. Misr. J. Ag. Eng.,15(1): 57-68 .

15- Misener, G. C. 1997. Relative performance of cup and pick type potato planters. Can. Agric. Eng. 21: 131-134.

16- Mohsenin, N. N. 1986. Physical properties of plant and Animal Materials. New York, Gordon and breach science publishers.

17- Sharma, A.K., and B.C. Srivastava. 1984. Performance evaluation of an automatic potato planter-cum intercultivator. 15 : 22 - 24 . 
تصميم و تصنيع جهاز تغذية جديد لآلة زراعة البطاطس

$$
\text { عاطف عزت اليماني }
$$

باحث بمعهُ بحوث الهندسة الزراعية - مركز البحوث الزراعية

يعتبر محصـول البطاطس من محاصيل الخضر الرئيسية في مصر حيث يزرع منه سنويا

حوالي 200 ألف فدان تعطى إنتاجية كلية تقدر بحوالى ب مليون طن موزعة على العروات الثلاث

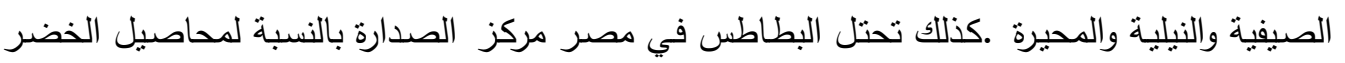
التصديرية حيث يتم سنويا تصدير كمية تقدر بحوالى 200 -250 ألف طن. وتعتبر عملية زراعة درنات

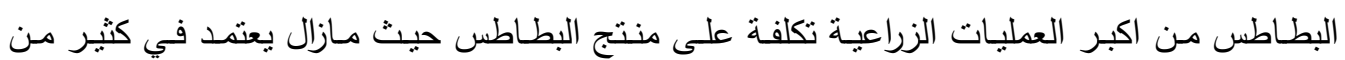

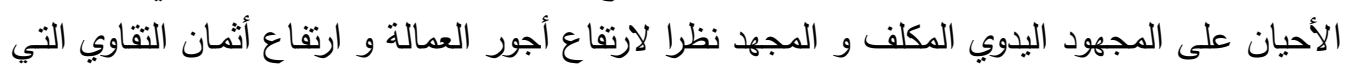

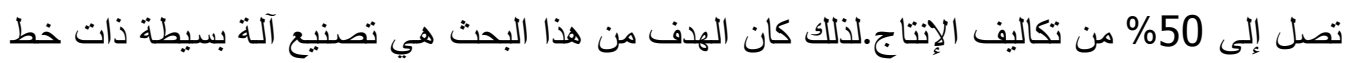

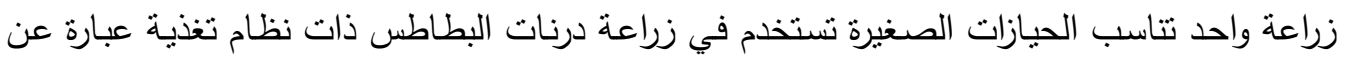
قرص دوار رأسي مركب على محيطة عدد ثمان أكواب تلقيم موزعة بالتساوي وذلك لتلافى مشاعلى مشاكل نقل

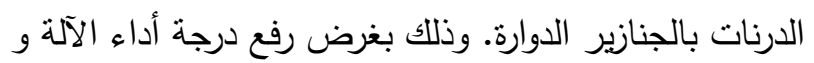

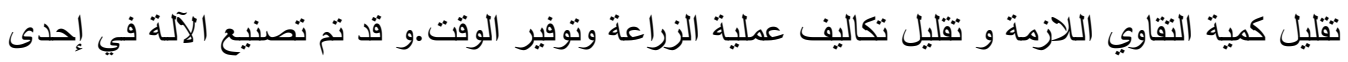

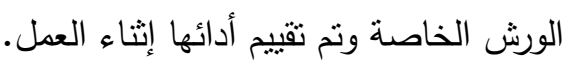

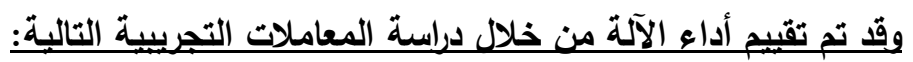

1 - السرعة الأمامية للجرار : تم إجراء الدراسة عند أربعة سر عات كانت 3.1 3. 3.8,

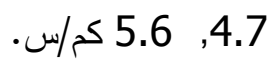


2- المسافة بين جور الزراعة على الخط الواحد : تم إجراء الدراسة عند أربعة مستويات كانت

$$
\text { 24, } 18
$$

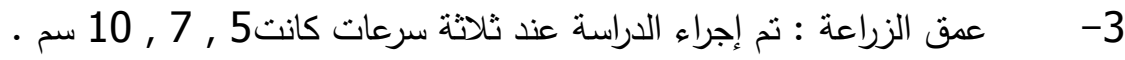

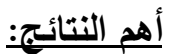

1- تأثثير زيادة السرعة الأمامية للآلة أدت إلى زيادة السعة الحقلية بينما كانت تؤدى إلى تقليل كل من

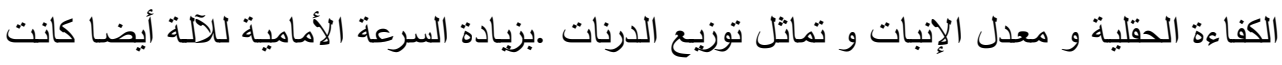
تتخفض تكاليف التتغيل بينما تزداد قيمة الدالة المعيارية للتكاليف.

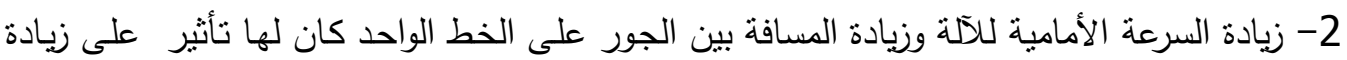

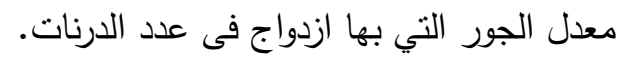

3- معدل الاستهلاك النوعي للوقود كان بقل بزيادة السرعة للآلة و بزيادة عمق الزراعة بينات بينما كان يزداد

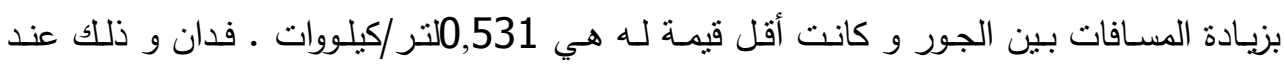
السرعة الأمامية 5,6 كيلومنز/ساعة و عمق الزراعة 10 سم.

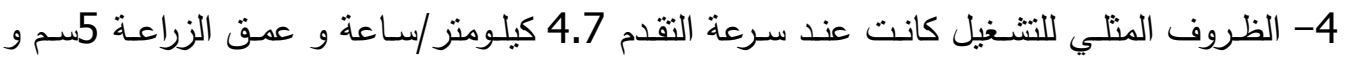
المسافة بين الجور 24سم وقد كانت تكاليف التتغيل عندها هي 34.7 جنية / الساعة بينما كانت الدالة المعيارية هي 233.15جنية /ساعة. 